Rok XVI (2021) | 1 (31) | S. 253-261

https://doi.org/10.12797/LV.16.2021.31.20

Agata Kwaśnicka-Janowicz ๑

Uniwersytet Jagielloński, Kraków

agata.kwasnicka-janowicz@uj.edu.pl

\title{
WITOLD TASZYCKI W DYSKUSJI O POCHODZENIU POLSKIEGO JĘZYKA LITERACKIEGO
}

Słowa klucze: historia języka, dialektologia historyczna, polszczyzna literacka

Keywords: history of language, historical dialectology, literary Polish

Spór o podstawy dialektalne polskiego języka ogólnego znany jako dyskusja o pochodzeniu polskiego języka literackiego ${ }^{1}$, zapoczątkowany przez wystąpienie Antoniego Kaliny (1883) z tezą o wielkopolskich podstawach polskiego języka literackiego, polemiczną wobec wcześniejszej hipotezy Franciszka Salezego Dmochowskiego (1864) o jego podstawach małopolskich, ma ponadstuletnią tradycję. Po wystąpieniach Kazimierza Nitscha kolejno w latach 1910 (Nitsch 1910) oraz 1913 (Nitsch 1913), w których postawione zostały nie tylko problem źródeł dialektalnych polskiego języka literackiego, ale także kwestia czasu powstania polskiego języka ogólnego, dyskusja przeniosła się na grunt ściśle językoznawczy (por. Walczak 1994). W latach 1949-1956 dyskusja weszła w fazę kulminacyjną, w której spór dotyczył głównie podstaw dialektalnych polszczyzny ogólnej. Dwie skrajne hipotezy: o wielkopolskim lub o małopolskim podłożu dialektalnym polszczyzny literackiej podzieliły środowisko językoznawcze. Głównymi zwolennikami sformułowanej przez K. Nitscha koncepcji wielkopolskiej byli: Władysław Kuraszkiewicz, Stanisław Rospond, Tadeusz

1 Wprowadzając za Bogdanem Walczakiem uściślające rozróżnienie, należy stwierdzić, że „termin "język literacki« bywa używany w dwu znaczeniach: w szerszym oznacza język ogólny, w węższym - pisaną odmianę języka ogólnego" (Walczak 1994: 35). 
Lehr-Spławiński, Stanisław Urbańczyk i Zdzisław Stieber. Ci dwaj ostatni uczeni doprowadzili ostatecznie do powstania kompromisowej, wielkopolsko-małopolskiej koncepcji pochodzenia polskiego języka literackiego (por. Dunaj 1980). W emocjonalnej dyskusji naukowej, podzielając koncepcję Aleksandra Brücknera $\left(1906^{2}\right)$, Witold Taszycki zajął stanowisko skrajnie małopolskie, dowodząc wraz z Tadeuszem Milewskim, że cały system gramatyczny polszczyzny literackiej wywodzi się z dialektu małopolskiego. Rok 1956 zakończył najbardziej owocną fazę dyskusji nad genezą polskiego języka literackiego, a jej wyniki opublikowane zostały w dwóch tomach studiów (Budzyk 1956; Stieber 1956b).

Skrajnie małopolska koncepcja W. Taszyckiego, upatrującego genezy polszczyzny literackiej w dialekcie małopolskim, najpełniej została przedstawiona przez autora w pracy o genezie języka literackiego w świetle faktów historycznojęzykowych, opublikowanej w czasopiśmie „Lingua Posnaniensis” w roku 1951 (Taszycki 1951). Artykuł ten stanowił kontynuację i rozwinięcie tez pracy badacza na temat małopolskich podstaw polszczyzny literackiej opublikowanej w miesięczniku „Twórczość” w roku 1949 (Taszycki 1949b).

Na problem genezy polszczyzny literackiej W. Taszycki zwrócił jednak uwagę już w roku 1930, kiedy włączając się w toczący się spór, opublikował pracę w „Przeglądzie Humanistycznym” (Taszycki 1930), w której opowiedział się za małopolską podstawą języka literackiego (narzecza kulturalnego), które jest „tworem w. XVI, mówiąc dokładniej, pierwszej połowy tego stulecia. Ugruntował się on [polski język literacki - A.K.-J.] na podstawie języka towarzyskiego (kulturalnego), który poprzedza pojawienie się języka literackiego" (ibid.: 328).

Włączenie się W. Taszyckiego w dyskusję o podstawach dialektalnych literackiej polszczyzny zaowocowało szeregiem prac, których efektem stało się wypracowanie na gruncie polskim nowej dyscypliny naukowej, czyli dialektologii historycznej. W latach 30. i 40. XX w. W. Taszycki opublikował szereg studiów obejmujących aspekt dawnych podziałów dialektalnych języka polskiego, m.in. geografii i chronologii przejścia ra- > re- (Taszycki 1934a); przejścia ja- > je- (Taszycki 1934b); staropolskich form czasu przeszłego robiłech, robilichmy (Taszycki 1946); przejścia $c h w->f$ - (Taszycki 1947b); zmiany tart $>$ tert, przyrostków $-k,-c$ i form podobnych (Taszycki 1947a), małopolskiego przejścia -ch > -k (Taszycki 1949a); wydał też ważną z metodologicznego punktu widzenia pracę o chronologii mazurzenia w języku polskim (Taszycki 1948).

2 Polemizując z tezą o wielkopolskich podstawach „języka piśmiennego”, A. Brückner pisał: „W XIII i XIV w. inicjatywa wielkopolskiej ziemicy już upada i Kraków mimo eksponowanego położenia dawno się na czoło wysunął, nie ma najmniejszej przyczyny, Małopolskę, wystawioną najbliżej i najsilniej na wpływy czeskie, odsądzać od zasługi stworzenia języka piśmiennego. [...] Specjalnych cech wielkopolskich nie ma również w naszych zabytkach, brak ich nawet w kazaniach gnieździeńskich” (Brückner 1906: 97). 
Opracowanie geografii i chronologii dialektalnych cech staropolszczyzny przeprowadził autor w oparciu o datowany i zlokalizowany materiał filologiczny, a postulatem badawczym nowej dyscypliny stało się sięganie do materiału historycznego. Dane pozyskiwane były z zabytków językowych, z komentarza metajęzykowego (wypowiedzi gramatyków i słownikarzy), w oparciu o materiały onomastyczne (tu równolegle z krytyką źródeł), ze zwróceniem uwagi na obserwacje z zakresu chronologii względnej, na końcu uzupełniane o dane ze współczesnych dialektów³

Oparcie głównie na metodzie filologicznej (analizie dawnych tekstów pisanych) spowodowało też w efekcie inne wobec teorii wielkopolskiej umiejscowienie punktu ciężkości w prowadzonej dyskusji o pochodzeniu polskiego języka literackiego. Jako zwolennik tezy małopolskiej W. Taszycki kładł nacisk na powstanie odmiany pisanej (języka literackiego), co wynikało z przyjętych założeń metodologicznych źródła pisane dostarczają danych odnoszących się tylko do odmiany pisanej (por. Dunaj 1980: 247). Zwolennicy teorii wielkopolskiej, z K. Nitschem na czele, postulowali oparcie się w dyskusji na metodach dialektologii synchronicznej, a tym samym skupiali się na początkach dialektu kulturalnego (odmiany mówionej) - metoda geografii językowej miała umożliwić retrospektywną rekonstrukcję przeszłości. Zgodnie też z przyjętą perspektywą badawczą K. Nitsch odróżniał mówiony dialekt kulturalny i (pisany) język literacki, stwierdzając, że: „fonetyczne i morfologiczne podstawy mówionego »dialektu kulturalnego« przyniesiono już do Krakowa z Wielkopolski. Na nich budował się z małopolskiego materiału słownikowego pisany "język literacki«" (Nitsch 1913: 38). Czas formowania się dialektu kulturalnego sieggałby tu wieku $\mathrm{XI}^{4}$, a „druga połowa w. XVI jest pierwszym szczytem polskiego języka literackiego. Idzie tu nie tylko o wysoki poziom stylistyczny, do jakiego wtedy doszedł, ale też o ostateczne ustalenie form w zakresie głosowni i odmian" (ibid.: 79).

W swoich powojennych pracach (Taszycki 1949b, 1951; Taszycki, Milewski 1956), korzystając z wyników dialektologii historycznej, operującej głównie metodą filologiczną, W. Taszycki przedstawił efekty analiz tekstów najdawniejszych zabytków języka polskiego, zarówno najstarszych polskich glos tekstów łacińskich, jak i późniejszych (XIV-XV w.) tekstów ciągłych. Polemizując z wielkopolską teorią K. Nitscha, potwierdził w nich obecność szeregu cech dialektalnych, które pozwoliły mu na stwierdzenie, że „na próżno szukać w nich będziemy oznak istnienia w Polsce wieku XII-XIV jakiegoś wzoru językowego, jakiejś językowej normy, którą by się piszący kierowali. [...] Brak normy językowej w Polsce XII-XIV w. sprzyjał przenikaniu dialektyzmów do zabytków pisanych" (Taszycki 1951: 33).

3 Swoje poglądy teoretyczne i metodologiczne w sprawie dialektologii historycznej przedstawił W. Taszycki w polemice z K. Nitschem, odpowiadając na jego artykuł pt. Co to jest dialektologia historyczna (Nitsch 1948) pracą o tym samym tytule, wydaną w roku 1956 (Taszycki 1956).

4 „Czyż w wieku XII a nawet XI nie było już także pewnych zaczątków dialektu kulturalnego?” (Nitsch 1913: 36). 
Potwierdzone w dalszych badaniach przesycenie elementami dialektalnymi zabytków nawet XV-wiecznych pozwalało autorowi na zaliczenie zabytków wieków XIV i XV do tekstów gwarowych ${ }^{5}$ i wyprowadzenie stąd tezy o późnym uformowaniu się polskiego języka literackiego. Autor dochodził tym do stwierdzenia, że skoro język polski pisanych zabytków średniowiecza nie był jeszcze znormalizowany, nie był on w istocie językiem ogólnopolskim. Tym bardziej więc nie spełniał przypisanej mu przez W. Taszyckiego definicji języka literackiego, którym język staje się dopiero jako narzędzie literatury o wysokich walorach artystycznych, o czym, według autora, w Polsce możemy mówić dopiero od drugiej połowy wieku XVI:

Przypada ta chwila osobliwa na środek, a zwłaszcza na 2. połowę w. XVI. Stało się to wówczas, gdy piśmiennictwo polskie pod względem artystycznym osiągnęło wysoki poziom, gdy język, jego organ, nabrał charakteru normy i tego społecznego prestiżu, który sprawił, że odtąd z pełną świadomością zamierzeń tym językiem posługiwać się będą pisarze w swoich dziełach, ludzie wykształceni w życiu publicznym i w miarę zżywania się z nim również w życiu prywatnym (ibid.: 56).

Za język literacki, w rozumieniu W. Taszyckiego, możemy więc uznać taki język, który zdobył swoją sprawność funkcjonalną i użytkową, pozwalającą na stworzenie w nim dzieł o wysokim poziomie artystycznym (por. tezy autora w artykule ogłoszonym w „Twórczości” w roku 1949 (Taszycki 1949b)). Zwolennik teorii małopolskiej przyjmował również, że polski język literacki rozwinął się z dialektu kulturalnego w wyniku działalności pisarskiej Mikołaja Reja, Stanisława Orzechowskiego, Łukasza Górnickiego, Jana Kochanowskiego, Piotra Skargi i innych twórców tej doby; a polski dialekt kulturalny „powstał ze środkowo-małopolskiego dialektu ludowego" (Taszycki 1951: 56).

Obecność cech dialektalnych w tekstach XIV- i XV-wiecznych, stwierdzona w badaniach W. Taszyckiego, świadczyła według Niego o braku w tym czasie jakichkolwiek norm czy tendencji normalizacyjnych. Dla badaczy istotniejszy wydaje się jednak fakt, że realizacje dialektalne w ówczesnych zabytkach nie są konsekwentne, niekiedy są wręcz rzadkie (por. Urbańczyk 1953a). Prowadzi to do wniosków o odbiciu w tekstach dokonujących się procesów normalizacyjnych i przejawów kształtujących się stopniowo ponaddialektalnych norm, a także prawdopodobnego istnienia, zarówno w XIV- i XV-wiecznych tekstach, jak też i w języku mówionym oficjalnym znacznej fakultatywności realizacji (Dunaj 1980: 250).

Sądy W. Taszyckiego o braku znormalizowania tekstów polskiego średniowiecza zrewidował w cytowanej niżej pracy z roku 1953 S. Urbańczyk, który zajął się zagadnieniem normy językowej w średniowiecznej polszczyźnie, dowodząc, że we wszystkich zabytkach staropolskich prawie zawsze obok pewnych cech i wpływów

5 To zdecydowane stanowisko, podzielające opinię A. Brücknera (1906), wyrażone w pracy z 1949 r., W. Taszycki złagodził nieco w artykule z roku 1951 (por. Taszycki 1949b, 1951). 
gwarowych, mniej lub bardziej silnych, są cechy wspólne, ponaddialektalne. Na dowód istnienia już w XIV w. normy ogólnopolskiej przytoczył przykłady z zabytków małopolskich (Kazania świętokrzyskie), w których pisarz stosuje wielkopolski spójnik iże, a nie małopolski ėze; w małopolskim Psałterzu floriańskim pojawia się realizacja $c h w$-, choć w Małopolsce mówiono wtedy $f$ - (fała, fila). Dla odmiany w wielkopolskich Kazaniach gnieźnieńskich obowiązuje południowopolskie ra-, ja- (rana, jako, nie rena, jeko), a także przyrostek -ek, nie -k (typ domek, nie domk). Jak pisał S. Urbańczyk:

Pokazałem, jak normy ponaddialektyczne, ogarnąwszy najpierw zabytki klasy literackiej, wdarły się z pewnym opóźnieniem do zapisek sądowych. Udowodniłem więc, że odkąd piszemy po polsku, obowiązują w zabytkach normy ponaddialektyczne, że zatem posiadamy język literacki od samego początku pisania po polsku (Urbańczyk 1953a: 88-89).

Istnienia normy językowej już w XIV-XV w. dowodził także w swojej pracy na temat pochodzenia polskiego języka literackiego w świetle dialektologii historycznej W. Kuraszkiewicz (1953), a za nim - T. Lehr-Spławiński (1956).

Postawiony przez W. Taszyckiego problem zróżnicowania dialektalnego polskich zabytków średniowiecza, wyprowadzony $\mathrm{w}$ toku filologicznych badań dialektologii historycznej, sprowokował liczne studia językowe, których argumenty wykorzystywane były w toczącej się dyskusji o pochodzeniu polskiego języka literackiego. Jakkolwiek skrajna teza o jedynie małopolskich podstawach polszczyzny literackiej, której zwolennikiem był W. Taszycki do końca (por. Taszycki, Milewski 1956 ${ }^{6}$ ), nie dawała się obronić, doprowadziła badaczy, w tym również S. Urbańczyka, do możliwości przyjęcia innego modelu kształtowania się polskiego języka literackiego. Chodzi tu o wzajemne relacje chronologiczne i genetyczne między powstaniem dialektu kulturalnego a powstaniem języka literackiego. W obu teoriach, zarówno wielkopolskiej, jak i małopolskiej, przyjmowano, że język literacki (język pisany) wytworzył

6 W 1956 r. po burzliwych dyskusjach W. Taszycki pisał: „Małopolski charakter gramatycznej i słownikowej struktury dialektu kulturalnego i szesnastowiecznego polskiego języka literackiego jest tak oczywisty, że w części przynajmniej zaczynają go uznawać także niektórzy »Wielkopolanie«" (Taszycki, Milewski 1956: 403). Miał tu na myśli prawdopodobnie T. Lehra-Spławińskiego, który w 2. wydaniu swej pracy Język polski. Pochodzenie, powstanie, rozwój (1951), formułując niezmiennie tezę o wielkopolskich podstawach gwarowych języka ogólnopolskiego, który dopiero w ciągu w. XV i XVI został wzbogacony elementami małopolskimi, a później jeszcze mazowieckimi i kresowymi (por. ibid.: 71-81), dokonał przeglądu protagonistów odżywającej po wojnie dyskusji o pochodzeniu polszczyzny literackiej, pomijając wśród zwolenników opcji wielkopolskiej (jako autora opracowania) własne nazwisko. Doprowadziło to T. Milewskiego do wniosku (przyjętego stąd zapewne przez W. Taszyckiego), że „T. Lehr-Spławiński [...] zdaje się ostatnio wycofywać z grona zwolenników teorii wielkopolskiej" (Milewski 1952: 330). To podejrzenie, a właściwie nieporozumienie T. Lehr-Spławiński stanowczo dementuje i prostuje w pracy z 1956 r. (por. Lehr-Spławiński 1956: 338). 
się na bazie znormalizowanego dialektu kulturalnego, czyli norma języka mówionego została przeniesiona do tekstów pisanych. W toczącej się w latach 50. dyskusji jedynie Z. Stieber, opisując procesy normalizacyjne literackiej polszczyzny przełomu XV i XVI w., stymulowane według Niego wpływem języka czeskiego (Stieber 1955, 1956a) ${ }^{7}$, zakładał, że:

Tak sformowany język był jednak przede wszystkim językiem pisanym, a nie mówionym. Trzeba z naciskiem stwierdzić, że w Polsce unifikacja języka pisanego poprzedziła unifikację języka mówionego ludzi wykształconych. Wynikało to z powszechnie uznanego dziś faktu, że unifikację języka pisanego przeprowadzili ostatecznie w w. XVI drukarze, przede wszystkim krakowscy (Stieber 1956a: 289).

Tezy Z. Stiebera, popartej w latach 90. przez B. Walczaka (1994), dowodzi stwierdzony przez $S$. Urbańczyka związek między stopniem literackości tekstów średniowiecznych (najbardziej literackie teksty to zabytki religijne, jak psałterz; najmniej literackie, a najbardziej użytkowe, to np. teksty prawne, jak roty przysiąg sądowych) a stopniem normalizacji ich języka. Ten przedstawia stosunek odwrotnie proporcjonalny: im bardziej literacki zabytek, tym mniej w nim dialektyzmów, czyli odstępstw od normy językowej, a im bardziej użytkowy tekst (zbliżony do ówczesnej mówionej polszczyzny), tym ich w nim więcej (Urbańczyk 1950, 1953b). Do podobnych wniosków prowadzi obserwacja odstępstw od kształtującej się normy językowej w zabytkach polskiego średniowiecza, które to odstępstwa interpretuje się jako przenikanie do tekstu rzeczywistej wymowy pisarza w chwilach dekoncentracji czy osłabienia uwagi, co dowodzi, że średniowieczni autorzy lub kopiści pisali wbrew swej gwarowej wymowie, stosując normę ogólnopolską, nieznaną polszczyźnie mówionej (Walczak 1994: 40). Ostatnim argumentem przemawiającym za prymarnością języka literackiego nad dialektem kulturalnym jest obserwacja słabego zróżnicowania dialektalnego języka mówionego XVI i XVII w. w ujęciu socjolingwistycznym (brak istotnych różnic między mową ludu a mową szlachty i mieszczaństwa), stwierdzona w badaniach S. Urbańczyka (1953b) nad tekstami literackimi (np. wskazujące na mazurzenie układy rymów) autorów XVI i XVII w.

7 Zdzisław Stieber przyjął rolę czeszczyzny jako arbitra w rywalizacji właściwości dialektalnych w kształtującej się odmianie ponaddialektalnej polszczyzny literackiej (rola czynnika zewnątrzjęzykowego) - pewne wpływy języka czeskiego utrwalają się w na przełomie XV i XVI w., kiedy na język polski zaczynają już oddziaływać czeskie druki. Stąd według Stiebera do języka literackiego weszły te formy wielkopolskie (brak mazurzenia, zachowanie -ch, typ źžódło - st.czes. zžiedlo, $u z z ̌ e l$, typ toponomastyczny na -sko, zachowanie $c h w$-) i małopolskie (ściągnięte stać, bać się, zachowanie ra-i zwykle ja-, przyrostki i końcówki z -ov-po twardej i miękkiej, typ domek i koniec, typ toponomastyczny na -in), które miały za sobą autorytet form zgodnych z czeskimi (Stieber 1956a: 288-289). Por. wprowadzenie do dyskusji teorii kontaktów językowych i tezy o intelektualizacji polszczyzny literackiej pod wpływem kontaktów z tzw. językami wysokoprestiżowymi, głównie łaciną i czeskim (Lewaszkiewicz 1994). 
Choć oparcie badań wypracowanej przez W. Taszyckiego dialektologii historycznej głównie na metodzie filologicznej stało się podstawą zarzutów o niepełny (czy wręcz zafałszowany) obraz badań, wynikający z pominięcia metody retrospektywnej (brak uwzględnienia stanu współczesnych dialektów) (por. negatywna ocena wyników pracy W. Taszyckiego na temat chronologii mazurzenia ${ }^{8}$ (Urbańczyk 1953a: 98)), jej ustalenia pozwoliły na szerszy ogląd stanu dialektalnego języka doby staropolskiej i udoskonalenie samej metody badań dialektologii historycznej. Wyśrodkowanie punktu ciężkości od próby ustalenia geografii zjawisk (dialektologia synchroniczna) do pytania o ich chronologię (dialektologia historyczna) doprowadziło też do konkluzji na temat oczekiwanego, potencjalnego warsztatu badawczego ukierunkowanego diachronicznie dialektologa, w którym „najpewniejsze wnioski na temat chronologii i geografii zjawisk dialektalnych uzyskuje badacz, jeśli dysponuje obfitym materiałem historycznym, mającym oparcie we współczesnych dialektach" (Dunaj 1981: 396).

Jak wynika z przedstawionej dyskusji, różnice poglądów na miejsce i czas formowania się polskiego języka literackiego wynikały więc z odmiennego definiowania pojęcia ,język literacki” (różnice terminologiczne), także odmiennej metody badawczej (synchronia - diachronia), co w konsekwencji przekładało się na modyfikacje proponowanych $\mathrm{w}$ dyskusji ram czasowych i modelów kształtowania się polskiego języka literackiego.

\section{Literatura}

BrüCKNer A., 1906, Dzieje języka polskiego, Lwów.

Budzy K. (red.), 1956, Pochodzenie polskiego jezyka literackiego, „Studia Staropolskie”, t. 3, Wrocław.

8 W swoich przypuszczeniach chronologicznych dotyczących czasu mazurzenia W. Taszycki oparł się na danych filologicznych dotyczących odróżniania w rękopisach XV-XVI w. szeregu $\check{c}, \check{z}, \check{s}$ od $c, z, s$ i wyraził pogląd, że mazurzenie powstało na Mazowszu dopiero w XV w., a Małopolskę ogarnęło dopiero w ciągu wieku XVI, nie mogło więc wejść do języka literackiego, kształtującego się w Małopolsce w wieku XV-XVI (por. Taszycki 1948). Uwzględniając trudności z ustaleniem chronologii mazurzenia na podstawie jedynie metody filologicznej, opartej na analizie ortografii zabytków (niedoskonałość i konwencja staropolskiej pisowni), całościowe wyniki pracy W. Taszyckiego oceniane są pozytywnie, zwłaszcza za negatywną weryfikację teorii o przedhistorycznym charakterze tego zjawiska: „Wykorzystując wskazówki z zakresu chronologii względnej, częścią wysunięte przez wcześniejszych badaczy, częścią zauważone samodzielnie, a także dane ortografów i gramatyków, W. Taszycki obalił dość mocno zakorzeniony wcześniej pogląd, jakoby mazurzenie powstało w dobie przedhistorycznej. Książeczka W. Taszyckiego wywołała niezwykle ożywioną dyskusję naukową. I choć datowanie mazurzenia na Mazowszu na XV w., zaś w Małopolsce dopiero na XVI jest trudne do utrzymania, to przecież historyczność tego zjawiska jest dzisiaj przyjmowana dość powszechnie” (Dunaj 1981: 395). 
Dмосноwski F.S., 1864, Nauka prozy, poezji i zarys piśmiennictwa polskiego, cz. III: Zarys piśmiennictwa polskiego, Warszawa.

Dunaj B., 1980, Pochodzenie polskiego języka literackiego, „Język Polski” LX, s. 245-254.

Dunaj B., 1981, Historia języka polskiego i dialektologia historyczna $w$ badaniach Witolda Taszyckiego, „Poradnik Językowy” nr 8-10, s. 393-40o.

Kalina A., 1883, Historya języka polskiego, t. 1: Formy gramatyczne języka polskiego do końca XVIII wieku, Lwów.

Kuraszkiewicz W., 1953, Pochodzenie polskiego języka literackiego w świetle wyników dialektologii historycznej, Wrocław; przedruk w: K. Budzyk (red.), Pochodzenie polskiego języka literackiego, „Studia Staropolskie”, t. 3, Wrocław 1956, s. 242-336.

LeHR-SpŁawiński T., 1951, Język polski. Pochodzenie, powstanie, rozwój, wyd. 2., Warszawa.

LeHR-SpŁAWIŃski T., 1956, Z rozważań o pochodzeniu polskiego języka literackiego, [w:] K. Budzyk (red.), Pochodzenie polskiego języka literackiego, „Studia Staropolskie”, t. 3, Wrocław, s. 337-363.

LEWASZKIEWICZ T., 1994, O potrzebie nowego spojrzenia na geneze polskiego języka literackiego (z uwzględnieniem tła ogólnoeuropejskiego), [w:] M. Kucała, Z. Krążyńska (red.), Studia historycznojęzykowe I, Kraków, s. 213-220.

Milewski T., 1952, Nowe prace o pochodzeniu polskiego języka literackiego, „Pamiętnik Literacki” XLIII, s. 312-334.

Nitsch K., 1910, Próba ugrupowania gwar polskich, „Rozprawy Wydziału Filologicznego PAU”, t. XLVI, Kraków, s. 336-365.

Nitsch K., 1913, O wzajemnym stosunku gwar ludowych i języka literackiego, cz. 1: Pochodzenie polskiego języka literackiego, cz. 2: Polskie dialekty kulturalne, cz. 3: Wpływ dialektu kulturalnego na dialekty ludowe, „Język Polski” I, s. 33-38, 79-83, 172-179, 281-287.

Nitsch K., 1948, Co to jest dialektologia historyczna?, „Biuletyn Polskiego Towarzystwa Językoznawczego" VIII, s. 119-122.

STIEBer Z., 1955, Wpływ czeszczyzny na kształtowanie się polskiego języka literackiego, [w:] M. Kudělka (red.), Česko-polský sborník vĕdeckých prací, t. 2, Praha, s. 27-37; przedruk w: Z. Stieber, Świat językowy Słowian, Warszawa 1974, s. 306-316.

STIEBer Z., 1956a, Udział poszczególnych dialektów $w$ formowaniu polskiego języka literackiego, [w:] idem (red.), Z dziejów powstawania języków narodowych i literackich, Warszawa, s. 97-120; przedruk w: idem, Świat językowy Słowian, Warszawa 1974, s. 272-294.

STIEBer Z. (red.), 1956b, Z dziejów powstawania języków narodowych i literackich. Materiały metodologicznej konferencji szkoleniowej Polskiej Akademii Nauk, Zakopane, marzec 1955, Warszawa.

TASzYCKi W., 1930, Spory o pochodzenie polskiego języka literackiego, „Przegląd Humanistyczny" 5, s. 323-333.

TAszYCKi W., 1934a, Z dawnych podziałów dialektycznych języka polskiego. Część I. Przejście ra- > re-, Archiwum Towarzystwa Naukowego we Lwowie, dział I, t. 6, z. 1, Lwów; przedruk w: idem, Rozprawy i studia polonistyczne, t. II, Wrocław 1961, s. 7-70.

TAszycki W., 1934b, Z dawnych podziałów dialektycznych języka polskiego. Część II. Przejście ja- > je-, Archiwum Towarzystwa Naukowego we Lwowie, dział I, t. 6, z. 2, Lwów; przedruk w: idem, Rozprawy i studia polonistyczne, t. II, Wrocław 1961, s. 71-148.

TASZYCKI W., 1946, Staropolskie formy czasu przeszłego robiłech, robilichmy, „Sprawozdania z Czynności i Posiedzeń Polskiej Akademii Umiejętności” XLVII, s. 7-10; przedruk w: idem, Rozprawy i studia polonistyczne, t. II, Wrocław 1961, s. 205-209. 
TAszycki W., 1947a, Dwa rozdziały z historycznej dialektologii polskiej: 1. Przejście połaczenia tart > tert. 2. Przyrostki -k, -c i formy podobne, „Sprawozdania z Czynności i Posiedzeń Polskiej Akademii Umiejętności” XLVIII, s. 311-316; przedruk w: idem, Rozprawy i studia polonistyczne, t. II, Wrocław 1961, s. 224-229.

TAszycki W., 1947b, Przejście chw > f w staropolszczyźnie, „Sprawozdania z Czynności i Posiedzeń Polskiej Akademii Umiejętności” XLVIII, s. 40-45; przedruk w: idem, Rozprawy i studia polonistyczne, t. II, Wrocław 1961, s. 217-223.

TAszycki W., 1948, Dawność tzw. mazurzenia w języku polskim, Warszawa.

TASZYCKI W., 1949a, O małopolskich formach grok 'groch', na nogak 'na nogach', robiłek 'robiłech=robiłem', „Język Polski” XXIX, s. 195-202; przedruk w: idem, Rozprawy i studia polonistyczne, t. II, Wrocław 1961, s. 210-216.

Taszycki W., 1949b, Powstanie i pochodzenie polskiego języka literackiego. Kraków kolebka literackiej polszczyzny, „Twórczość” V, z. 12, s. 100-117.

TAszyCKi W., 1951, Geneza polskiego języka literackiego w świetle faktów historycznojęzykowych, „Lingua Posnaniensis” III, s. 206-242; przedruk w: K. Budzyk (red.), Pochodzenie polskiego języka literackiego, „Studia Staropolskie”, t. 3, Wrocław 1956, s. 30-59.

TAszycki W., 1956, Co to jest dialektologia historyczna?, „Zeszyty Naukowe Uniwersytetu Jagiellońskiego IX. Prace Językoznawcze”, nr 2, s. 59- 71.

Taszycki W., Milewski T., 1956, Polski język literacki powstał w Małopolsce. Głos w dyskusji nad pochodzeniem literackiej polszczyzny, [w:] K. Budzyk (red.), Pochodzenie polskiego języka literackiego, „Studia Staropolskie”, t. 3, Wrocław, s. 364-436.

URBAŃCZy K S., 1950, W sprawie polskiego języka literackiego. I. O dawności dialektu kulturalnego, „Język Polski” XXX, s. 97-109.

URBAŃCZYк S., 1953a, Głos w dyskusji o pochodzeniu polskiego języka literackiego, „Pamiętnik Literacki” XLIV, s. 196-216; przedruk w: K. Budzyk (red.), Pochodzenie polskiego języka literackiego, „Studia Staropolskie”, t. 3, Wrocław 1956, s. 82-101.

URBAŃCZY K S., 1953b, Jaka polszczyzną mówił Jan Kochanowski i jego rówieśnicy, „Język Polski” XXXIII, s. 214-224.

Walczak B., 1994, Geneza polskiego języka literackiego, „Teksty Drugie” nr 3 (27), s. 35-47.

\section{Witold Taszycki in the Discussion on the Origin of the Polish Literary Language Summary}

The article presents the position of Witold Taszycki in the debate, which was the most intensive in 1940 and 1950s, on the origin of the Polish literary language. Taszycki was a supporter of the extreme thesis according to which the literary Polish originated from Lesser Poland, where it developed in the mid-16th century. In opposition to the Greater Poland theory, the extreme views of Witold Taszycki on the time and place of shaping the Polish literary language resulted not only from the author's beliefs, but also from a different terminology and research method used by the researcher. 